\title{
ПРИКЛАДНІ АСПЕКТИ ЗАСТОСУВАННЯ ЛІКАРСЬКИХ РОСЛИН РОДИНИ RANUNCULACEAE В ЕТНОМЕДИЦИНІ ТА ФАРМАЦІЇ
}

\author{
Лях В. Р., Конечна Р. Т.
}

\section{ВСТУП}

Історія вивчення лікарських рослин така ж довга, як й історія людства. Завдяки різноманітності складу активних компонентів цілющі рослини здавна використовуються у традиційній медицині різних народів світу. Сучасний інтерес до застосування лікарської рослинної сировини сприяє зростанню наукових досліджень та розробок, завдяки чому відкрито та досліджено багато різних сполук еволюційних рівнів, таких як стероїдні сапоніни, алкалоїди, терпеноїди та глікозиди. Розширені дослідження, на зразок хемотаксономії, молекулярної філогенетики та фармакологічної активності, направлені на покращення розуміння та дослідження лікарських рослин.

Останнім часом в Україні, як і взагалі у світі, відзначається зростання зацікавленості науковців до вивчення, впровадження в практику та застосування лікарської рослинної сировини й одержаних на іiі основі фітопрепаратів як 3 лікувальною, так i профілактичною метою за багатьох захворювань. Встановлено, що серед загальної кількості лікарських призначень засоби рослинного походження в різних країнах становлять від $20 \%$ до $60 \%$.

Застосування лікарських засобів рослинного походження має низку переваг, зумовлених тим, що рослини містять різні групи біологічно активних речовин, які надають комплексну дію на організм, володіють низькою токсичністю, м'якістю дії і низьким рівнем алергічних реакцій. Лікувальна дія рослин базується на наявному в них комплексі фізіологічно активних речовин, що мають різноманітну будову і властивості. Хімічний склад рослин залежить також і від генетичних особливостей виду.

Численні дослідження лікарських рослин та фітопрепаратів цілком зміцнили позиції фітотерапії як методу лікування. Сучасний фармацевтичний ринок України та світу насичений лікарськими препаратами, особливо синтетичного походження, які мають свої 
переваги, проте і багато недоліків. 3 огляду на це споживачі все більше надають перевагу препаратам природнього походження.

Рослинні препарати мають низку переваг над синтетичними препаратами, зокрема: не часто викликають алергічні реакції, до них не розвивається адаптація макро- і мікроорганізмів, вони малотоксичні й добре переносяться хворими. За силою дії та фармакологічною активністю багато рослинних лікарських препаратів не завжди можна замінити синтетичними. Сьогодні, володіючи порівняно великим асортиментом рослинної сировини $\mathrm{i}$ препаратів широкого спектру дії, лікарі мають можливість широко використовувати їх у комплексному лікуванні різноманітних захворювань.

Натепер наночастинки металів використовуються в багатьох сферах життєдіяльності людини, а саме в терапії захворювань, для цільової доставки ліків, як антисептики та компоненти косметологічних засобів, ефективні напівпровідники та біосенсори тощо. Зелений синтез - перспективний метод синтезу наночастинок за допомогою біологічних систем, що використовує екологічні, технологічні, хімічні та виробничі процеси. Одним із напрямів зеленого синтезу є використання рослинної сировини як системи відновлення та стабілізації утворених металічних наночастинок. Рослини родини жовтцевих (Ranunculaceae) $\epsilon$ потенційно перспективною сировиною в зеленому синтезі, оскільки містять значну кількість біологічно активних речовин, а саме алкалоїди, флавоноїди, органічні кислоти, сапоніни, макрота мікроелементи та ін.

Метою роботи було провести аналіз даних літературних джерел щодо поширення, хімічного складу, аспектів використання окремих видів лікарських рослин родини Ranunculaceae, а саме калюжниці болотної (Caltha palustris) та пшінки весняної (Ficaria verna) у фітотерапії та в зеленому синтезі наночастинок, установити доцільність їх вивчення, впровадження та перспектив їх практичного застосування в технології лікарських засобів.

\section{1. Ботанічна характеристика, розповсюдження та хімічний склад рослин родини Ranunculaceae}

Родина Ranunculaceae включає близько 60-ти родів і понад 2000 видів рослин, представлених переважно в помірних і холодних областях земної кулі. Вони широко поширені по всіх континентах, 
особливо в Північній зоні. В Арктиці число родів і видів незначне, але вони складають важливий елемент флори. У тропіках і субтропіках Ranunculaceae зустрічаються значно рідше і в основному в гірських районах. Тут також $є$ й ендемічні роди рослин родини Ranunculaceae.

Чимало водних рослин є представниками цієї родини. У річках, канавах часто зустрічається Ranunculus aquatilis (який можна розглядати або як підрід роду Ranunculus, або як представник роду Batrachium). В умовах сильного зволоження зростають види роду Калюжниця (Caltha) ${ }^{1}$.

Ranunculus діляться на 4 підродини: Hydrastidoideae, Ranunculoideae, Thalictroideae i Kingdonioideae.

У цілому рослини родини Ranunculaceae - зазвичай багаторічні трави 3 коротким, іноді бульбоподібним кореневищем (у деяких видів він замінюється подовженим столоном), і у різних видів розрізняються листям. Квітки у Ranunculaceae розташовані у верхоквіткових суцвіттях - від гроноподібних до мітловидних, рідше поодинокі, двостатеві. Забарвлення квіток дуже різноманітне - від білих (анемона, жовтець водяний), синіх (переліска, аконіт, живокіст), жовтих (жовтець, калюжниця, купальниця) до яскравочервоних (адоніс). Найчастіше ця яскраве забарвлення пов'язане з чашолистками. Ranunculus - це комахозапилювані рослини. Плоди в них можуть бути різноманітними - складна листянка (Caltha), горішок (Ranunculus aquatilis), соковиті багатонасінні ягоди ${ }^{2}$.

Значення Ranunculus для людини пов'язано передусім 3 їхніми лікарськими i декоративними властивостями. Багато видів Ranunculus містять різноманітні біологічно активні речовини, зокрема алкалоїди, що в тій чи іншій мірі $є$ отруйними, тому в природі рослини не часто поїдаються дикими тваринами. Проте ці ж речовини в певних дозах можна використати як біологічно активні. Крім алкалоїдів, багато видів Ranunculus (аконіт, живокіст, горицвіт весняний, сон-трава) містять такі активно діючі речовини, як глікозиди. Багато видів рослин родини Ranunculus активно використовуються як декоративні рослини (купальниця, анемони, борець, ломиніс та ін.) $)^{3}$.

1 Жизнь растений / под ред. академика АН СССР А.Л. Тахтаджяна. Москва : Просвещение, 1982. Т. 6: Цветковые растения. 544 с.

${ }^{2}$ Стекольников Л.И., Мурох В.И. Целебные кладовые природы. Минск, 1979. 260 с.

${ }^{3}$ Юркевич И.Д., Мишенин И.Д. Лекарственные растения и их применение. Минск, 1976. $590 \mathrm{c}$. 


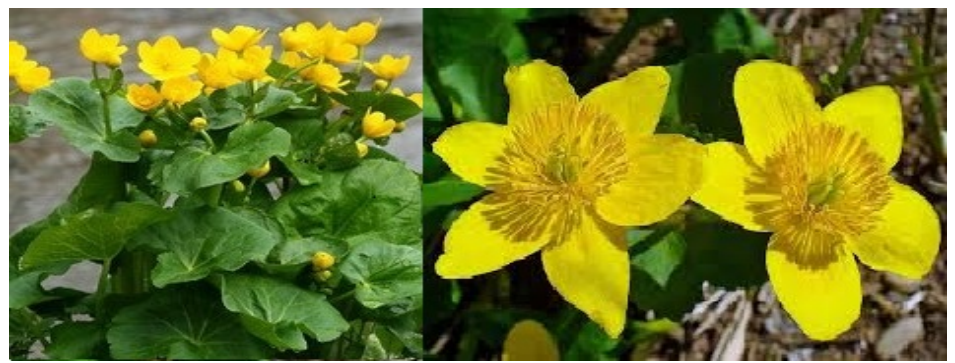

Pис. 1. Caltha palustris

Цікавими об'єктами для дослідження виступають представники родини Ranunculaceae - Калюжниця болотна (Caltha palustris) та Пшінка весняна (Ficaria verna). Ці рослини здавна застосовувались у народній медицині багатьох країн, проте ще досі залишаються недостатньо вивченими.

Caltha palustris - це рослина родини Жовтицевих (Ranunculaceae), родy Калюжниця (Caltha). У народі часто поширені назви болотянок, болох, воташ, жабник, жаб'яча трава, жовтковий колір, калужниця, кальожниця, лапики, латач. Це трав'яниста рослина 3 прямостоячим, простим чи зверху галузистим стеблом, що має висоту до 20-50 см. Листки великі, зарубчасті, нижні листки великі округлосерцевидні, а верхні майже сидячі, наполовину стеблообгортні, мають нирковидно-серцевидні пластинки.

Забарвлення блискучих листків темно-зелене, розміщення на стеблі чергове. Корені в рослини нитковидні, зібрані в пучок. Квіти оцвітини овальні або яйцеподібні, яскраво-жовті, 14-24 мм завдовжки, квіти 2,5-3,0 см у діаметрі, п'ять пелюсток розміщуються на довгих квітконіжках Цвіте рослина у квітні-травні. Перше цвітіння рослини починається лише на 10-й рік іiї життя. Плоди листянки, які містять до 10-ти чорних блискучих насінин, випадають після дозрівання в травні-липні.

Caltha palustris поширена в Українських Карпатах у високогірних районах ${ }^{4}$. Росте на берегах водойм, у вологих луках, озерах, заболочених лісах, по болотах, уздовж річок у повільно текучих та стоячих водах, біля сирих каналів ${ }^{5,6}$.

${ }^{4}$ Ukrainian Biodiversity Information Network. URL: http://www.ukrbin.com.

5 Bruni, A., Bonora, A., Dall'Olio, G. Protoanemonin Detection in Caltha palustris. Journal of Natural Products. 1986. Vol. 49 № 6. P. 1172-1173. doi: http://doi.org/ 10.1021/np50048a058. 


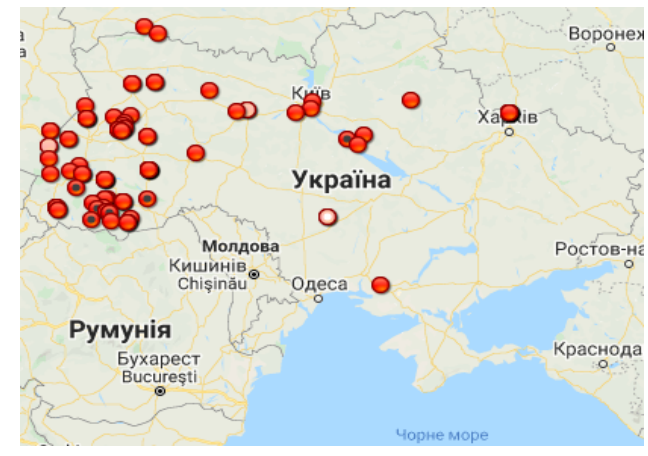

Рис. 2. Поширення Caltha palustris в Україні

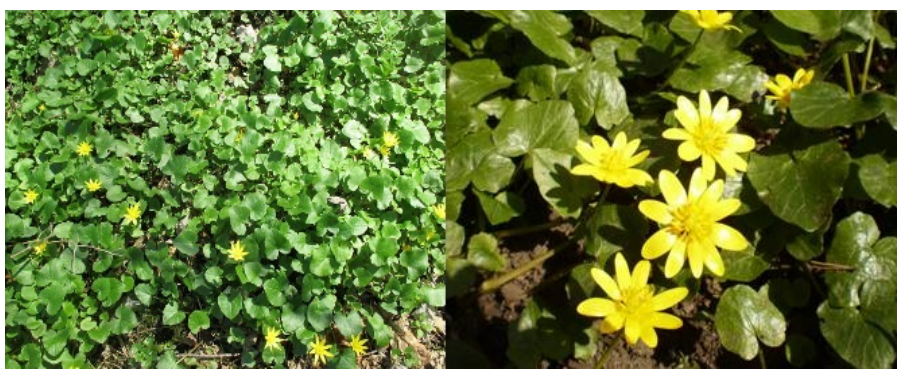

\section{Рис 3. Ficaria verna}

Пшінка весняна Ficaria verna - ще один представник родини Жовтицевих (Ranunculaceae). Місцева назва - маслянка. Латинська назва походить від слова, що в перекладі означає винна ягода ${ }^{7}$.

Рослина ефемероїдна, ранньовесняна 3 бульбоподібно потовщенним коренем при основі стебла, заввишки 9-30 см. Рослина тіньовитривала.

Стебло висхідне, тонке, просте або розгалужене у верхній частині, як і вся рослина, голе. Соковиті листки (2-5 см у діаметрі) зверху блискучі, округло-серцеподібні з виїмчасто-зарубчастими краями; верхні кутасті або трохи лопатеві, при основі широкосерцеподібно виїмчасті, з розсунутими лопатями, що не перекривають одна одну. При основі черешків є білі, видовжені вивідкові бруньки. Нижні листки довгочерешкові, середні та верхні на коротших черешках.

${ }^{6}$ Гродзінський А.М. Лікарські рослини. Київ, 1989. 480-481с.

${ }^{7}$ Морозюк С.С., Протопопова В.В. Трав'янисті рослини. Київ, 1986. 160 с. 
Квітки по одній-дві на верхівці гілок, правильні (2,5-3,5 см у діаметрі). Оцвітина подвійна. Чашечка 3 трьох вільних листочків. Чашолистки (6-10 мм завдовжки) широкояйцеподібні, жовтуватозеленуваті, тонкоплівчасті. Віночок (10-17 мм завдовжки) роздільнопелюстковий, з 8-10 видовженими оберненояйцеподібними, золотисто-жовтими, блискучими пелюстками. При основі пелюсток $є$ медова залозка, вкрита лусочкою. Цвіте в березні-квітні. Плід збірна сім'янка. Плодик (2-4 мм завдовжки) до основи сплюснутий ${ }^{8}$.

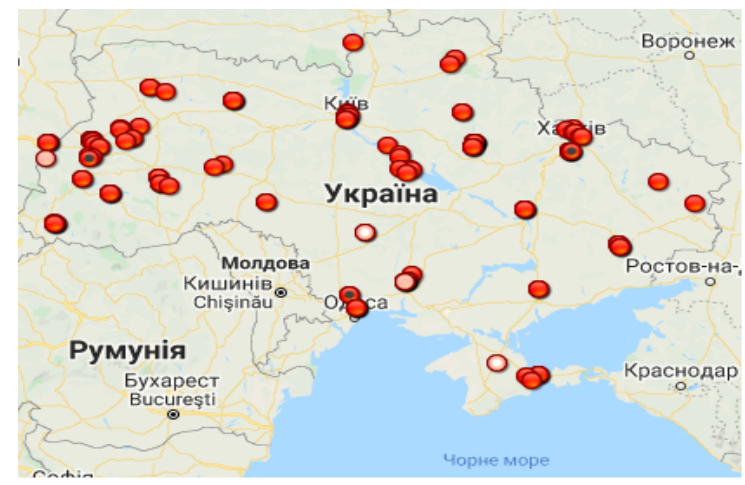

\section{Рис 4. Поширення Ficaria verna в Україні}

Поширена по всій Україні. Зростає в лісах, переважно широколистяних, але також хвойно-широколистих, частіше в сирих i вогкуватих, нерідко вздовж водотоків, у чагарниках. Також зустрічається і на відкритих місцях - степах, луках, узліссях i галявинах листяних лісів, а також у заплаві і на берегах річок, струмків ${ }^{9}$. Часто утворює масові скупчення.

\section{2. Застосування в етномедицині та фармації}

Caltha palustris та Ficaria verna є неофіціальними рослинами. Caltha palustris застосовується в народній медицині і в гомеопатії.

У народній медицині України Caltha palustris найчастіше застосовують зовнішньо як протизапальний і знеболюючий засіб у разі ран, опіків, забиттів, ревматизму, нейродерматитів, екземи тощо ${ }^{10}$.

${ }^{8}$ Дари лісів / Ю.Я. Єлін та ін. Київ, 1979. 312 с.

${ }^{9}$ Ukrainian Biodiversity Information Network. URL: http://www.ukrbin.com.

10 Калюжниця болотна, лікарські властивості, отруйність та протипоказання. 2019. URL: https://toxicplants.pp.ua/index.php/otrujni-roslini/rodyna-zhovtetsevi/606kalyuzhnitsya-bolotna-likarski-vlastivosti-otrujnist-ta-protipokazannya. 
Відвар або настій трави Caltha palustris у невеликих дозах вживають внутрішньо під час гарячкових станів, коклюшу, бронхіту, астми, порушення обміну речовин, діатезу, анемії, цинги, болісних менструацій і карциноми матки, а також як сечогінний засіб у разі водянки й захворювань сечовивідних органів ${ }^{11}$.

У тибетській медицині настій квітів використовували для лікування асциту. У гомеопатії рослину, зокрема свіжі квітучі рослини, частіше використовують для лікування бронхіту та кашлю, порушення менструального циклу тощо ${ }^{10,12}$. Також сировина Caltha palustris часто застосовується в лікарських засобах східної медицини.

Caltha palustris входить до складу препаратів, які представлені на вітчизняному фармацевтичному ринку. До них належить комплексний гомеопатичний препарат Геліум-Хель, у формі крапель для перорального застосування, iї виробник - німецька фірма Biologische Heilmittel Heel Gmb Н. Засіб має імуномодулюючу, протизапальну, дезінтоксикаційну та дренажну дію, яка базується на активації захисних сил організму i нормалізації порушених функцій за рахунок речовин рослинного, мінерального та тваринного походження, що входять до складу препарату. Препарат застосо вується в разі хронічних захворювань, що часто загострюються; інфекцій, що потребують стимуляції неспецифічного імунітету; після наслідків токсичної дії медикаментозної терапії (антибіотики, хіміотерапія, радіотерапія) $)^{13}$.

Ще однією фірмою, яка пропонує однокомпонентні гомеопатичні засоби з Caltha palustris, є американська компанія WHP (Washington Homeopatic Products. Ця компанія займається виробництвом i реалізацією власних гомеопатичних засобів та засобів, що виробляються іншими компаніями світу. Препарати Caltha palustris $€$ у вигляді таблеток, гранул та пілюль ${ }^{14}$.

${ }^{11}$ Elicitor-induced Accumulation of Protoanemonin in Caltha palustris L. Journal of Plant Physiology / A. Bonora et al. 1987. Vol. 131. № 5. P. 489-494. DOI: http://doi.org/10.1016/s0176-1617(87)80291-2.

${ }^{12}$ Agnieszka S., Bozena O.-M. Effects of polysaccharide fractions isolated from Caltha palustris L. on the activity of phagocytic cells \& humoral immune response in mice with collagen-induced arthritis: A comparison with methotrexate. Indian Journal of Medical Research. 2017. Vol. 145. № 2. 229-236 p.

${ }^{13}$ Брокгауз Ф.А., Ефрон И.А. Энциклопедический словарь Брокгауза и Ефрона. Санкт-Петербург, 1890-1907.

${ }^{14}$ Орач Д.А., Орач О.Д. Рослини дарують здоров'я. Фітотерапевтичний енциклопедичний довідник / За ред. К.В. Форманчука. Львів, 2007. 568 с. 
Ficaria verna застосовуються тільки в народній медицині. Свіже листя Ficaria verna застосувують у гомеопатії ${ }^{15}$.

Ficaria verna має сечогінні, відхаркувальні, проносні, протизапальні, ранозагоювальні та кровоочисні властивості, а також застосовується в лікуванні бронхіту, трахеїту, запору, геморою, шкірних висипань, діатезу, вугрів, гінгівіту, стоматиту, поліартриту, ран. При цьому в лікувальних цілях використовують надземну частину і коріння молодої рослини.

У народній медицині України найчастіше використовується внутрішньо для лікування бронхіту, трахеїту, запору та зовнішньо - у разі геморою, шкірних висипів, діатезу, вугрів, стоматиту, подряпин та ран.

У народній медицині Білорусії Ficaria verna застосовують у разі укусів змій. Чай з висушеної рослини використовують за шкірних захворювань як кровоочисний, знеболюючий i протизапальний засіб. Відвар використовують для полоскань ротової порожнини в разі пародонтозу й ураження ясен, а також для компресів, примочок і обмивань гнійних ран ${ }^{16,17}$.

У гомеопатії Ficaria verna частіше використовують для лікування геморою. Буарон - сімейна і незалежна фармакологічна компанія, що спеціалізується на виробництві гомеопатичних ліків з 1932 року, випускала антигемороїдальну мазь Avenoc, до складу якої входила Ficaria verna. Мазь полегшує симптоми геморою івідновлює комфорт щоденної фізіологічної діяльності шляхом придушення ректальної кровотечі, усунення болю, свербіння і печіння ${ }^{18}$.

Екстракт Ficaria verna представлений у фармакопеях Франції, США та РФ. Застосовується як освіжаючий та кондиціонуючий дерматологічний засіб ${ }^{19}$. Лікарська рослинна сировина Ficaria verna ma Caltha palustris є перспективним об'єктом для фармакогностичних, фітохімічних, фармакологічних досліджень.

Досліджувані рослини застосовують у комплексних лікарських препаратах різного спектру дії. Дані аналізу літературних джерел, зокрема патентів щодо засобів на основі Ficaria verna ma Caltha palustris, представлені в табл. $1^{20}$.

${ }_{16}^{15}$ Барабанов Е.И. Ботаника. Москва. Издательский центр «Академия», 2006. 237 с.

${ }^{16}$ Жизнь растений / под. ред. А.Л. Тахтаджяна. Москва, 1981. Том 5. Часть 2: Цветковые растения. $511 \mathrm{c}$.

${ }^{17}$ Пешкова Г.И., Шретер А.И. Растения в домашней косметике и дерматологии. Москва, 2001. 684 с.

18 Лекарства из Германии. Мазь Avenoc.URL:http://www.lekarstva-iz-germani.com.

19 Лекарственные препараты. URL:https://medzai.net.

${ }^{20}$ European Patent Office. URL: https://worldwide.espacenet.com. 
Таблиця 1

Засоби на основі Caltha palustris та Ficaria verna

\begin{tabular}{|c|c|c|c|}
\hline Назва засобу & Автор & $\begin{array}{c}\text { Номер } \\
\text { патенту }\end{array}$ & Застосування \\
\hline $\begin{array}{c}\text { Китайська } \\
\text { лікарська суміш } \\
\text { для лікування } \\
\text { простатиту }\end{array}$ & $\begin{array}{l}\text { Huang, } \\
\text { Xing }\end{array}$ & $\begin{array}{l}\text { CN1341427 } \\
\text { A 2002-03-27 }\end{array}$ & $\begin{array}{l}\text { Застосовується для } \\
\text { лікування простатиту, } \\
\text { гіперплазії } \\
\text { передміхурової залози, } \\
\text { орхіту, епідидиміту, } \\
\text { уретриту, генітального } \\
\text { герпесу, олігурії, } \\
\text { гідронефрозу та циститу. }\end{array}$ \\
\hline $\begin{array}{l}\text { Китайський } \\
\text { лікарський засіб } \\
\text { для лікування } \\
\text { опіків }\end{array}$ & $\begin{array}{l}\text { Liu, } \\
\text { Baning }\end{array}$ & $\begin{array}{l}\text { CN104288359 } \\
\text { A 2015-01-21 }\end{array}$ & $\begin{array}{l}\text { В'яжучий, } \\
\text { протизапальний засіб, } \\
\text { що сприяє загоєнню ран, } \\
\text { зменшенню ексудації } \\
\text { та набряків, полегшенню } \\
\text { болю, зменшує } \\
\text { можливість утворення } \\
\text { пухирів, запобігає } \\
\text { інфекційним проявам. } \\
\end{array}$ \\
\hline $\begin{array}{c}\text { Лікарський } \\
\text { препарат, що } \\
\text { застосовується } \\
\text { під час гострого } \\
\text { подагричного } \\
\text { артриту, та } \\
\text { спосіб його } \\
\text { застосування }\end{array}$ & $\begin{array}{l}\text { Zhang, } \\
\text { Lizhu }\end{array}$ & $\begin{array}{l}\text { CN103585604 } \\
\text { A 2014-02-19 }\end{array}$ & $\begin{array}{l}\text { Покращує кровообіг, } \\
\text { усуває застій крові, } \\
\text { сприяє розсмоктуванню } \\
\text { затверділостей, усуває } \\
\text { набряки та зменшує } \\
\text { больові відчуття. } \\
\text { Застосовується } \\
\text { безпосередньо на місці } \\
\text { набряку й болю, миттєво } \\
\text { відчувається } \\
\text { охолоджуючий ефект. }\end{array}$ \\
\hline $\begin{array}{c}\text { Нетоксичний } \\
\text { спрей для } \\
\text { лікування опіку } \\
\text { та технології } \\
\text { його отримання }\end{array}$ & $\begin{array}{l}\text { Huang, } \\
\text { Haining; } \\
\text { Tang, } \\
\text { Hongquan; } \\
\text { Xu, } \\
\text { Wenbing; } \\
\text { Wang, } \\
\text { Jianjun }\end{array}$ & $\begin{array}{l}\text { CN107281303 } \\
\text { A } 2017-10-24\end{array}$ & $\begin{array}{l}\text { Ефективно полегшує біль } \\
\text { у разі опіків, прискорює } \\
\text { загоєння уражених } \\
\text { ділянок, має } \\
\text { бактерицидну дію. }\end{array}$ \\
\hline
\end{tabular}


Продовження таблиці 1

\begin{tabular}{|c|c|c|c|}
\hline $\begin{array}{c}\text { Засіб для } \\
\text { догляду за } \\
\text { порожниною } \\
\text { рота, для } \\
\text { покращення } \\
\text { видалення } \\
\text { зубного каменю } \\
\text { ультразвуковим } \\
\text { способом. }\end{array}$ & $\begin{array}{l}\text { Hu, } \\
\text { Xiaokun; } \\
\text { Liu, } \\
\text { Mei; } \\
\text { Qin, } \\
\text { Tianmu }\end{array}$ & \begin{tabular}{|l|} 
CN109381385 \\
A 2019-02-26
\end{tabular} & $\begin{array}{l}\text { Допомагає знімати } \\
\text { зубний камінь } \\
\text { ультразвуком невеликої } \\
\text { сили, що запобігає } \\
\text { кровотечі й інфекції. }\end{array}$ \\
\hline $\begin{array}{c}\text { Китайська } \\
\text { лікарська суміш } \\
\text { для лікування } \\
\text { розладу } \\
\text { поперекових } \\
\text { хребців. }\end{array}$ & $\begin{array}{c}\text { Zhang, } \\
\text { Zhongjian }\end{array}$ & \begin{tabular}{|l|} 
CN103263621 \\
A 2013-08-28
\end{tabular} & $\begin{array}{l}\text { Сприяє циркуляції та } \\
\text { усуненню застою крові. } \\
\text { Використовується для } \\
\text { лікування поперекової } \\
\text { гіперестрогенії, пролапсу } \\
\text { поперекового } \\
\text { міжхребцевого диску, } \\
\text { ревматоїдного артриту. }\end{array}$ \\
\hline $\begin{array}{c}\text { Суміш } \\
\text { традиційного } \\
\text { китайського } \\
\text { засобу для } \\
\text { лікування } \\
\text { гіперплазії } \\
\text { молочної залози }\end{array}$ & $\begin{array}{c}\text { Dai, } \\
\text { Huaying; } \\
\text { Bi, Jianyao; } \\
\text { Yang, } \\
\text { Pengfei; Yu, } \\
\text { Hong-qiang; } \\
\text { Liu, Rong }\end{array}$ & \begin{tabular}{|c|} 
CN105770751 \\
A 2016-07-20
\end{tabular} & $\begin{array}{l}\text { Сприяє кровообігу, } \\
\text { пом’якшенню та } \\
\text { розсмоктуванню твердої } \\
\text { маси, поліпшенню } \\
\text { імунітету, врівноваженню } \\
\text { ендокринної системи для } \\
\text { лікування різних типів } \\
\text { гіперплазії молочної } \\
\text { залози. }\end{array}$ \\
\hline $\begin{array}{c}\text { Косметика для } \\
\text { відбілювання } \\
\text { шкіри, } \\
\text { що містить } \\
\text { специфічні } \\
\text { рослинні } \\
\text { екстракти, або } \\
\text { їх засоби для } \\
\text { лужної обробки } \\
\end{array}$ & $\begin{array}{l}\text { Tachi-kawa, } \\
\text { Makoto }\end{array}$ & $\begin{array}{c}\text { JP2001206819 } \\
\text { A 2001-07-31 }\end{array}$ & $\begin{array}{l}\text { Косметичний засіб } \\
\text { ефективно пригнічує } \\
\text { вироблення меланіну, } \\
\text { відбілює шкіру та } \\
\text { полегшує веснянки. }\end{array}$ \\
\hline $\begin{array}{c}\text { Шкірна } \\
\text { композиція, що } \\
\text { містить екстракт } \\
\text { Ficaria verna як } \\
\text { підсилювач } \\
\text { провідної } \\
\text { властивості } \\
\text { шкіри } \\
\end{array}$ & $\begin{array}{l}\text { Leclere, } \\
\text { Jacques }\end{array}$ & $\begin{array}{c}\text { FR2872041 } \\
\text { A1 }\end{array}$ & $\begin{array}{l}\text { Косметична композиція } \\
\text { містить ефективну } \\
\text { кількість екстракту як } \\
\text { агента для підвищення } \\
\text { провідної здатності } \\
\text { шкіри. }\end{array}$ \\
\hline
\end{tabular}


Продовження таблиці 1

\begin{tabular}{|c|c|c|c|}
\hline $\begin{array}{c}\text { Композиція } \\
\text { для покращення } \\
\text { бар'єрної } \\
\text { функції ураженої } \\
\text { шкіри }\end{array}$ & $\begin{array}{l}\text { Hansenne, } \\
\text { Isabelle }\end{array}$ & $\begin{array}{c}\text { US200900533 } \\
37 \mathrm{~A} 1\end{array}$ & $\begin{array}{l}\text { Композиція та спосіб } \\
\text { поліпшення бар'єрної } \\
\text { функції ураженої шкіри } \\
\text { шляхом нанесення на } \\
\text { уражену шкіру } \\
\text { композиції. }\end{array}$ \\
\hline
\end{tabular}

\section{3. Синтез наночастинок срібла в екстракті Caltha palustris}

3 урахуванням перспективності використання рослин родини Ranunculaceae Caltha palustris та Ficaria verna досліджуються нові можливості застосування їх на практиці. Натепер багато науковців працюють над пошуками нових способів синтезу наночастинок, які б мали мінімальний шкідливий вплив на навколишнє середовище. Тому увага дослідників зосередилися на так званому зеленому наносинтезі.

У методах зеленого синтезу використовуються різні біологічні природні речовини, такі як мікроорганізми, цілі рослини, тканини та плоди рослин, рослинні екстракти, морські водорості та мікрорідини для відновлення та стабілізації наночастинок. Синтез наночастинок із використанням рослинних екстрактів має низку переваг перед іншими екологічними методами синтезу, оскільки рослини широко розподілені, легко масштабовані, легко доступні, безпечні в обігу та дешевші ${ }^{21}$.

Ці шляхи синтезу $є$ одноразовими і часто призводять до виробництва наноматеріалів із контрольованим розміром та формою - дві особливості, які надзвичайно важливі для біологічної активності наночастинок. На відміну від хімічного та фізичного методів, які потребують використання високотоксичних хімічних речовин або високоенергетичних джерел, зелений наносинтез $\epsilon$ енергетично вигідною, нетоксичною альтернативою ${ }^{22,23,24}$.

${ }^{21}$ Mittal, A.K., Chisti, Y., Banerjee, U.C. Synthesis of metallic nanoparticles using plant extracts. Biotechnol. Adv. 31, 346-356 (2013).

${ }^{22}$ Intracellular biosynthesis of $\mathrm{Au}$ and $\mathrm{Ag}$ nanoparticles using ethanolic extract of Brassica oleracea L. and studies on their physicochemical and biological properties. J Environ. Sci / P. Kuppusamy et al. 2015. № 29. P. 151-157.

${ }^{23}$ Green synthesis of silver nanoparticles from leaf extract of Mimusops elengi, Linn. for enhanced antibacterial activity against multi drug resistant clinical isolates / P. Prakash et al. 2013. № 108. P. 255-259.

${ }^{24}$ Orbaek, A.W., McHale, M.M., Barron, A.R.: Synthesis and characterization of silver nanoparticles for an undergraduate laboratory. J. Chem. Edu. 92, 339-344 (2014). 
Під час синтезу наночастинок зазвичай відбувається хімічне відновлення металу, а для біосинтезу підходять сполуки, які можуть виступати відновниками. Багато біомолекул у рослинах, такі як білки/ферменти, амінокислоти, полісахариди, алкалоїди, алкогольні сполуки та вітаміни, можуть брати участь у біоредукції, утворенні та стабілізації наночастинок металів. Потенціал зменшення іонів та зменшення здатності рослин, які залежать від присутності в рослинах поліфенолів, ферментів та інших хелатоутворюючих речовин, мають критичний вплив на кількість виробництва наночастинок.

Зелений синтез - перспективний метод синтезу наночастинок за допомогою біологічних систем ${ }^{25}$. На відміну від інших методів наносинтезу (плазмохімічного, газового, електровибуху, термічного розкладання, радіолізу, випаровування в електричній дузі), в процесі зеленого синтезу використовуються доступні нетоксичні речовини, зменшено кількість етапів процесу, знижено кількість відходів. Крім того, перевагами цього методу є економія реагентів та енергії, а сам синтез проходить за нормальних температур без використання вакуума.

Одним із напрямів зеленого синтезу $є$ використання рослинної сировини як системи відновлення та стабілізації утворених металічних наночастинок. Механізм біологічного синтезу наночастинок досі до кінця не з'ясований, але відомо, що під час наносинтезу зазвичай відбувається хімічне відновлення металу, яке зумовлене дією ферментів, вуглеводів, вітамінів, фенольних сполук, терпеноїдів, флавоноїдів, танінів, які в значній кількості містяться в клітинах рослин.

Розробка методів отримання наночастинок за допомогою біологічної сировини базується на використанні ферментних систем біологічних об'єктів та властивих для них біологічних сполук. Одним 3 основних способів біосинтезу наночастинок $\epsilon$ виготовлення наночастинок золота та срібла за допомогою екстрактивних речовин рослинного походження.

Отримують сферичні чи квазісферичні золоті, срібні та біметалічні золотосрібні наночастинки шляхом хімічного відновлення відповідних розчинних сполук золота та срібла (тетрахлороауратної кислоти, нітрату срібла або, в разі одержання біметалічних частинок, їхній

${ }^{25}$ Нанотехнології у фармації на теренах України. Перспективи «зеленого синтезу». Нанотехнології у фармації та медицині / Р.С. Ванько та ін. 2018. С. 17-18. 
суміші в розбавленому водному розчині) під дією рослинних метаболітів, екстрагованих із відварів рослинної сировини ${ }^{26}$.

Як фітохімічний елемент використовуються фітоекстракти, які виготовляються відварюванням свіжої рослинної сировини: листя магнолії Кобус, платану, хурми, гінкго тощо. Також як фітохімічні ємності використовуються водні екстракти 3 листя магнолії голої Magnolia denudata Desr., магнолії зірчастої M. stellata (Siebold \& Zucc.) Maxim., зеленого чаю підвидів Camellia sinensis var. sinensis (L.) Kuntze i C. sinensis var. Assamica (J.W. Mast.) Kitam., трави ортосифона тичинкового Orthosiphon stamineus Benth. та звіробою продірявленого Нурericum perforatum L. Загалом, усі наведені рослини характеризуються здатністю накопичувати в значних кількостях ряд метаболітів із відновлювальною активністю: амінокислоти, білки, флавоноїди, фенольні сполуки, таніни, вуглеводи тощо, що є ключовим фактором успішного синтезу та стабілізації наночастинок.

Caltha palustris та Ficaria verna є перспективними об'єктами для зеленого наносинтезу, оскільки містять у своєму складі речовини метаболіти з відновлювальною активністю. Доцільно досліджувати екстракти рослин щодо перспектив використання для «зелених» нанотехнологій та розширення можливостей використання рослин як сировини для синтезу наночастинок срібла та інших металів.

\section{ВИСНОВКИ}

Багато рослин родини Ranunculaceae мають лікувальні властивості та здавна використовуються в медицині. Багато рослин занесені до Фармакопеї, але більшість застосовуються лише в народній медицині.

Базуючись на результатах проведеного дослідження та провівши аналіз літературних даних щодо поширення Caltha palustris, основних аспектів іiі використання в медицині та фармації, можна зробити висновок, що Caltha palustris є доволі перспективною лікарською рослиною родини Ranunculaceae. Результати роботи свідчать про перспективи використання Caltha palustris як лікарської сировини для проведення подальших грунтовних досліджень, оскільки рослина має давній досвід використання в етномедицині та містить цінні біологічно активні сполуки.

${ }^{26}$ Спосіб одержання наночастинок срібла та золота / Я.Б. Блюм та ін. Патент України на корисну модель № 86778 від 10.01.2014. 
Враховуючи хімічний склад Ficaria verna, досвід використання в народній медицині та практичне застосування ii екстрактів у країнах Європи та Америки, доцільно провести комплексне дослідження рослини 3 метою включення ï до списку офіційних рослин України. Застосування рослинної сировини Ficaria verna в медицині $€$ перспективним напрямом для створення нових лікарських та лікувально-профілактичних засобів.

\section{АНОТАЦІЯ}

Останнім часом в Україні, як і взагалі у світі, відзначається зростання зацікавленості науковців до вивчення, впровадження в практику та застосування лікарської рослинної сировини й одержаних на iï основі фітопрепаратів як 3 лікувальною, так i профілактичною метою за багатьох захворювань. Рослини родини жовтцевих (Ranunculaceae) є потенційно перспективною сировиною в даному аспекті, оскільки містять значну кількість біологічно активних речовин і здавна застосовуються етномедициною.

Проаналізовано наукові літературні дані щодо ботанічної характеристики, розповсюдження, хімічного складу, аспектів використання окремих видів лікарських рослин родини Ranunculaceae, а саме калюжниці болотної (Caltha palustris) та пшінки весняної (Ficaria verna) у фітотерапії та в «зеленому» синтезі наночастинок. Установлено доцільність їх комплексного дослідження та впровадження в практичне застосування технологією лікарських засобів та нанотахнологією.

Результати роботи свідчать про доцільність та перспективи використання рослинної сировини Caltha palustris та Ficaria verna як лікарської сировини для проведення подальших грунтовних досліджень, оскільки рослини мають давній досвід використання в етномедицині та містять цінні біологічно активні сполуки.

\section{ЛІТЕРАТУРА}

1. Жизнь растений / под ред. академика АН СССР А.Л. Тахтаджяна. Москва : Просвещение, 1982. Т. 6: Цветковые растения. $544 \mathrm{c.}$

2. Стекольников Л.И., Мурох В.И. Целебные кладовые природы. Минск, 1979. 260 с.

3. Юркевич И.Д., Мишенин И.Д. Лекарственные растения и их применение. Минск, 1976. 590 с 
4. Ukrainian Biodiversity Information Network. URL: http://www.ukrbin.com.

5. Bruni, A., Bonora, A., Dall'Olio, G. Protoanemonin Detection in Caltha palustris. Journal of Natural Products. 1986.. Vol. 49. № 6. P. 1172-1173. doi: http://doi.org/10.1021/np50048a058

6. Гродзінський А.М. Лікарські рослини. Київ, 1989. С. 480-481.

7. Морозюк С.С., Протопопова В.В. Трав'янисті рослини. Київ, 1986. $160 \mathrm{c}$.

8. Дари лісів / Ю.Я. Єлін та ін. Київ, 1979. 312 с.

9. Калюжниця болотна, лікарські властивості, отруйність та протипоказання. 2019. URL: https://toxicplants.pp.ua/index.php/ otrujni-roslini/rodyna-zhovtetsevi/606-kalyuzhnitsya-bolotna-likarskivlastivosti-otrujnist-ta-protipokazannya.

10. Elicitor-induced Accumulation of Protoanemonin in Caltha palustris L. Journal of Plant Physiology / A. Bonora et al. 1987. Vol. 131. № 5. P. 489-494. DOI: http://doi.org/10.1016/s0176-1617(87)80291-2.

11. Agnieszka, S., Bozena, O.-M. Effects of polysaccharide fractions isolated from Caltha palustris L. on the activity of phagocytic cells \& humoral immune response in mice with collagen-induced arthritis: A comparison with methotrexate. Indian Journal of Medical Research. 2017. Vol. 145. № 2. P. 229-236.

12. Брокгауз Ф.А., Ефрон И.А. Энциклопедический словарь Брокгауза и Ефрона. Санкт-Петербург, 1890-1907.

13. Орач Д.А., Орач О.Д.. Рослини дарують здоров'я. Фітотерапевтичний енциклопедичний довідник / за ред К.В. Форманчука. Львів, 2007. $568 \mathrm{c.}$

14. Барабанов Е.И. Ботаника. Москва : Издательский центр «Академия», 2006. $237 \mathrm{c.}$

15. Жизнь растений / под. ред. А.Л. Тахтаджяна. Москва, 1981. Том 5. Часть 2: Цветковые растения. $511 \mathrm{c.}$

16. Пешкова Г.И., Шретер А.И. Растения в домашней косметике и дерматологии. Москва, 2001. 684 с.

17. Лекарства из Германии. Мазь Avenoc. URL: http://www.lekarstva-iz-germani.com.

18. Лекарственные препараты. URL: https://medzai.net.

19. European Patent Office. URL: https://worldwide.espacenet.com.

20. Mittal, A.K., Chisti, Y., Banerjee, U.C. Synthesis of metallic nanoparticles using plant extracts. Biotechnol. Adv. 2013. 31. 346-356. 
21. Intracellular biosynthesis of $\mathrm{Au}$ and $\mathrm{Ag}$ nanoparticles using ethanolic extract of Brassica oleracea L. and studies on their physicochemical and biological properties. J. Environ. Sci / P. Kuppusamy et al. 2015. № 29. P. 151-157.

22. Green synthesis of silver nanoparticles from leaf extract of Mimusops elengi, Linn. for enhanced antibacterial activity against multi drug resistant clinical isolates / P. Prakash et al. 2013. № 108. P. 255-259.

23. Orbaek A.W., McHale M.M., Barron A.R. Synthesis and characterization of silver nanoparticles for an undergraduate laboratory. 2014. № 92. P. 339-344.

24. Нанотехнології у фармації на теренах України. Перспективи «зеленого синтезу». Нанотехнології у фармації та медищині / Р.С. Ванько та ін. 2018. С. 17-18.

25. Спосіб одержання наночастинок срібла та золота / Я.Б. Блюм та ін. Патент України на корисну модель № 86778 від 10.01.2014.

\section{Information about the authors: Liakh V. R.,}

Postgraduate Student at the Department of Technology of Biologically Active Substances, Pharmacy and Biotechnology

Lviv Polytechnic National University 12, Stepana Bandery str., Lviv, 79000, Ukraine

Konechna R. T.,

Candidate of Pharmaceutical Sciences, Associate Professor at the Department of Technology of Biologically Active Substances, Pharmacy and Biotechnology

Lviv Polytechnic National University 12, Stepana Bandery str., Lviv, 79000, Ukraine 